

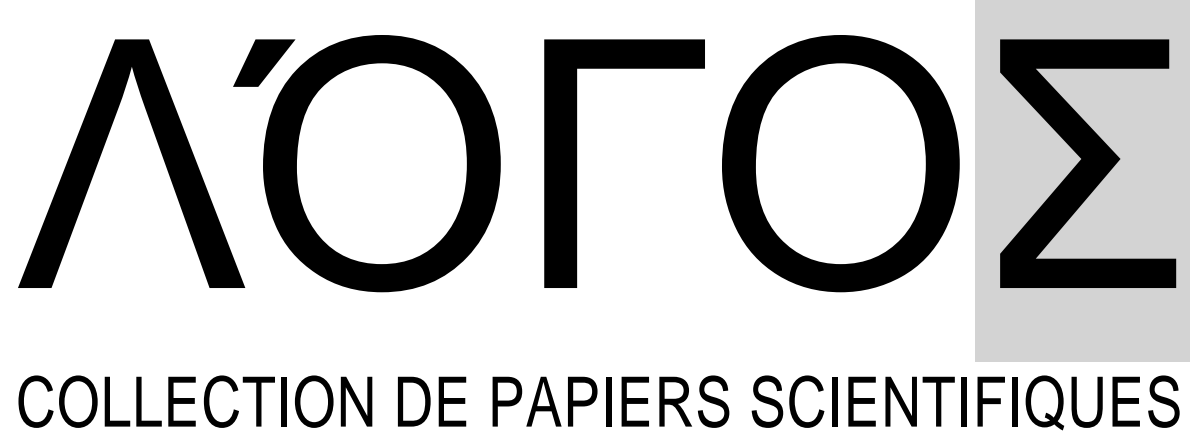

SUR LES MATÉRIAUX DE LA CONFÉRENCE SCIENTIFIQUE ET PRATIQUE INTERNATIONALE

«TENDANCES SCIENTIFIQUES DE LA RECHERCHE FONDAMENTALE ET APPLIQUÉE» 30 OCTOBRE 2020

\section{VOLUME 2}

Strasbourg • République française 
Président du comité d'organisation: Holdenblat $M$.

Responsable de la mise en page: Bilous $T$.

Responsable de la conception: Bondarenko I.

\section{T 35 Tendances scientifiques de la recherche fondamentale et} appliquée: collection de papiers scientifiques «^ОГО $\Sigma$ » avec des matériaux de la conférence scientifique et pratique internationale (Vol. 2), 30 octobre, 2020. Strasbourg, République française: Plateforme scientifique européenne.

ISBN 978-2-37467-128-4 («La Fedeltà», République française)

DOI 10.36074/30.10.2020.v2

Les résumés et articles des participants à la conférence multidisciplinaire scientifique et pratique internationale "Tendances scientifiques de la recherche fondamentale et appliquée», qui s'est tenue à Strasbourg le 30 octobre 2020, sont présentés.

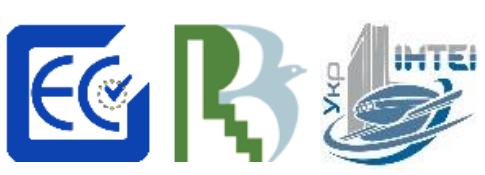

La conférence est incluse dans le catalogue des conférences scientifiques internationales; approuvé par ResearchBib et UKRISTEI (Certificat № 450 du 05/10/2020); est certifié par Euro Science Certification Group (Certificat № 22182 du 04/10/2020).

Le matériel de la conférence sera accessible au public selon les termes de la licence Creative Commons Attribution 4.0 International (CC BY 4.0).

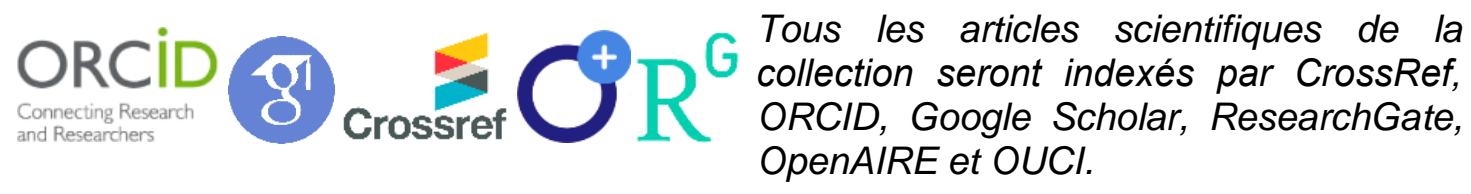

UDC $001(08)$

(C) Le collectif des participants à la conférence, 2020

(C) Collection de papiers scientifiques «^ОГОО $», 2020$ 


\section{CONTENU}

\section{SECTION VII. SCIENCES CHIMIQUES}

ОТРИМАННЯ ЦИНК(ІІ) ОКСИДУ МЕТОДОМ ОСАДЖЕННЯ

Гуцул X.P. .7

\section{SECTION VIII.}

\section{SCIENCES BIOLOGIQUES}

АНАЛІЗ ВИДІВ РОДИНИ RANUNCULACEAE JUSS ФЛОРИ НАЦІОНАЛЬНОГО ПРИРОДНОГО ПАРКУ ОЛЕШКІВСЬКІ ПІСКИ» (ХЕРСОНСЬКА ОБЛАСТЬ, УКРАЇНА)

Науково-дослідна група:

Мельник Р.П., Непрокін А.В., Ложкіна О.І., Конюшенко І.П. .10

КОМБІНАЦІЙНА ЗДАТНІСТЬ БАТЬКІВСЬКИХ ФОРМ ТЮТЮНУ ЗА ОСНОВНИМИ ОЗНАКАМИ ТА ЇХ КЛАСИФІКАЦІЯ

Глюдзик-Шемота М.Ю.

ОСОБЛИВОСТІ ТЕРМОРЕГУЛЯЦІЇ ОРГАНІЗМУ ЛЮДИНИ В УМОВАХ ПОМІРНОГО КЛІМАТУ

Невмержицький В.В.

ХАРАКТЕРИСТИКА КІЛЬКОСТІ ДІАПАУЗНИХ ЛИЧИНОК ТА ЛЯЛЕЧОК КАШТАНОВОÏ МІНУЮЧОÏ МОЛІ (CAMERARIA OHRIDELLA DESCHKA) У РІЗНИХ МІСЦЯХ М. КАУНАСА (ЛИТВА)

Кичак О.О., Кавун Е.М.

\section{SECTION IX.}

\section{SCIENCES MÉDICALES}

APPARTENANCE AUX TYPOLOGIES HUMAINES CONTRIBUE-T-IL AUX CARACTÉRISTIQUES DU SYNDROME MÉTABOLIQUE?

Tkachenko E., Prilutsky M., Moulim M.

AUTOIMMUNE THYROIDITIS IN PATIENTS WITH CHRONIC HEPATITIS C Nevkhoroshev Y., Tkemaladze D.

COMPARATIVE ASSESSMENT OF THE STUDENTS ATTENTION LEVEL DURING FACE-TO-FACE AND DISTANCE CLASSES

Research group

Kadnai O.S., Mozgova T.P., Leshchyna I.V., Fedorchenko S.V.

RELATIONSHIP BETWEEN FAMILIES OF PATIENTS WITH DEMENTIA TO DIAGNOSIS AND TREATMENT

Kozhyna H.M., Zelenska K.O., Kaploukh O.M. 
4 - Tendances scientifiques de la recherche fondamentale et appliquée • Volume 2

THE DEGREE OF NERVOUS AND MENTAL STRESS AND ANXIETY IN INTERNALLY DISPLACED PERSONS (IDPED) AND RESIDENTS OF THE KHARKIV REGION

Research group:

Kozhyna H.M., Zelenska K.O., Kraskovska T.Y., Zelenska H.M. 32

ДИФЕРЕНЦІЙНІ ЗМІНИ СТОМАТОЛОГІЧНОГО СТАТУСУ У ВІКОВОМУ АСПЕКТІ

Стецик М.О., Стецик А.О., Костенко С.Б.

ДОСЛІДЖЕННЯ ЯКОСТІ СНУ СТУДЕНТІВ-МЕДИКІВ

Гармаш І.В., Дегтяр К.О.

ОСОБЛИВОСТІ РЕНТГЕНОДІАГНОСТИКИ ХІЛОТОРАКСУ

Гуманець К.Р., Марченко І.О.

ПСИХОГІГІЕНА, ЯК РОЗДІЛ НАУКИ НАЦІЛЕНИЙ НА ПОПЕРЕДЖЕННЯ ВИНИКНЕННЯ ДЕПРЕСІЇ, ІПОХОНДРІЇ ТА АСТЕНІЇ

Тереник С.А., Старусева В.В.

\section{SECTION X.}

VÉTÉRINAIRE

ВПРОВАДЖЕННЯ ІНТЕРАКТИВНИХ ТЕХНОЛОГІЙ ПРИ ВИКЛАДАННІ ФАРМАКОЛОГІЇ У ПРОЦЕСІ ПІДГОТОВКИ МАЙБУТНІХ ФАХІВЦІВ ВЕТЕРИНАРНОї МЕДИЦИНИ

Жванія О.І.

\section{SECTION XI.}

PSYCHOLOGIE ET SOCIOLOGIE

БАГАТОРІВНЕВИЙ ПІДХІД В ЛІКУВАННІ ХВОРИХ ІЗ СИНДРОМОМ АЛКОГОЛЬНОЇ ЗАЛЕЖНОСТІ

Науково-дослідна група:

Харківська А.І., Уніченко А.В., Чухраєва О.М., Мельник А.Ю. .48

ГЕНДЕРНЫЕ РОЛИ СЕМЬИ КАК БАРЬЕР В РАЗВИТИИ ИНДИВИДУАЛЬНОСТИ

Бугачевская Е.В.

\section{SECTION XII.}

\section{COMMUNICATIONS SOCIALES ET CULTUROLOGIE}

ПРОБЛЕМА ВПРОВАДЖЕННЯ ЕЛЕКТРОННОГО ДОКУМЕНТООБІГУ В РОБОТУ СЛУЖБ ДОКУМЕНТАЦІЙНОГО ЗАБЕЗПЕЧЕННЯ УПРАВЛІННЯ Курило Н.О. 


\title{
COMPARATIVE ASSESSMENT OF THE STUDENTS ATTENTION LEVEL DURING FACE-TO-FACE AND DISTANCE CLASSES
}

\author{
RESEARCH GROUP \\ Oleksii Kadnai \\ $4^{\text {th }}$ year student of the First medical faculty \\ Kharkiv National Medical University \\ Tetiana Mozgova \\ Doctor of Medical Sciences, Professor \\ Professor of the Department of Psychiatry, Narcology, \\ Medical Psychology and Social Work \\ Kharkiv National Medical University \\ Iryna Leshchyna \\ Candidate of Medical Sciences, \\ Associate Professor of the Department of Psychiatry, Narcology, Medical \\ Psychology and Social Work \\ Kharkiv National Medical University \\ Svitlana Fedorchenko \\ Candidate of Medical Sciences, \\ Assistant of the Department of Neuropathology and Neurosurgery \\ Kharkiv Medical Academy of Postgraduate Education
}

UKRAINE

Introduction. Everyone needs to focus their attention to get certain information. Many factors affect the level of attention. Medical university students require an increased level of attention during their studies, because the success of future practice depends on it. The life of a medical university student involves many factors that reduce the level of attention during classes, but now we are faced with a new, distance, form of studying that has become a guarantee of student safety during the COVID-19 pandemic. [1]. This form of education has become quite new for medical universities, in this regard, there is a necessity to explore the level of attention of students during offline and online learning $[2,4]$.

Purpose of the study. To conduct a comparative assessment of the level of attention of $4^{\text {th }}$ year students during face-to-face and distance classes at clinical departments.

Materials and methods. The objects of the study were thirty 4th year students of the Medical Faculty, who attended online and offline classes at clinical departments. Psychodiagnostic questionnaire research method was used.

The Munsterberg test, which aims to determine the level of concentration, was chosen as a questionnaire. According to the standard algorithm for evaluating test results, the levels are regarded as: low, medium, high. [3] Students were asked to go through it during breaks between the halves of the classes.

Results. The results of the study showed that during face-to-face classes the levels of attention were distributed as follows: 9 students (30\%) had a high level of 
attention; the average level of attention was noted in the largest number of students and amounted to 17 students (56.7\%); low level of attention was found in 4 students $(13.3 \%)$.

Data on distance learning were distributed as follows. There was a significant decrease in the number of students with a high level of attention and amounted to 4 students (13.3\%). Instead, there was a significant increase in students with an average level of attention, and amounted to 25 students (83.3\%). At the same time, only 1 student (3.3\%) showed a low level of attention during distance learning.

\section{Conclusions.}

1.There are significant changes in the structure of the distribution of attention levels of medical university students during face-to-face and distance learning classes. During distance classes, there was a significant increase in students with average attention, which was accompanied by a decrease in the number of students with high attention by 2.26 times and an even more significant decrease in the number of students with low attention by 4.43 times.

2. Online learning is not an obstacle to successful studying, subject to the willful efforts of students and abide by the usual recommendations to increase attention: getting rid of unnecessary external stimuli, providing isolation from unnecessary digital devices and ensuring an optimal lifestyle.

\section{References:}

[1] Barbara J Patterson \& Anne M Krouse (2017). Student outcomes of distance learning in nursing education: an integrative review. CIN: Computers, Informatics, Nursing, 5(11), p.475-488 doi: 10.1097/NXN.0b013e3182573ad4.

[2] Yao Zhang \& Haoyu Zhang, Xindong Ma, Qian Di (2020). Mental Health Problems during the COVID-19 Pandemics and the Mitigation Effects of Exercise: A Longitudinal Study of College Students in China. Int $J$ Environ Res Public Health, 25(5), doi: 10.1097/NXN.0b013e3182573ad4.

[3] Максимова Л.А. \& Смирнов А.В. (2018). Психологическая диагностика сфер личности. Екатиренбург: Водяха ISBN 978-5-7186-1131-1.

[4] Shuang-Jiang Zhou \& Li-Gang Zhang, Lei-Lei Wang, Zhao-Chang Guo, Jing-Qi Wang, Jin-Cheng Chen, Mei Liu, Xi Chen, Jing-Xu Chen (2020). Prevalence and socio-demographic correlates of psychological health problems in Chinese adolescents during the outbreak of COVID-19. Eur Child Adolesc Psychiatry, (29)6 doi: 10.1007/s00787-020-01541-4. 


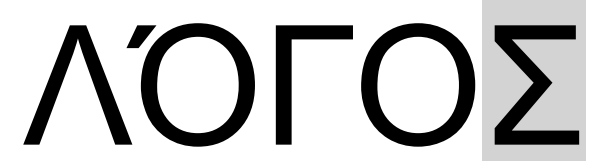

COLLECTION DE PAPIERS SCIENTIFIQUES

SUR LES MATÉRIAUX DE LA CONFÉRENCE SCIENTIFIQUE ET PRATIQUE INTERNATIONALE

«TENDANCES SCIENTIFIQUES DE LA RECHERCHE FONDAMENTALE ET APPLIQUÉE»

30 octobre 2020 • Strasbourg, République française

\author{
VOLUME 2
}

\begin{abstract}
Ukrainien, russe, français et anglais
Les matériaux sont imprimés dans le texte de l'auteur Le comité organisateur ne partage pas toujours la position des auteurs Pour l'exactitude de ce matériel, les auteurs portent la responsabilité
\end{abstract}

Signé pour impression le 30.10.2020. Format 60×84/16.

Papier offset. Arial type. Impression numérique

Feuilles imprimées conditionnées 7,56.

Un tirage de 100 exemplaires.

Imprimé à partir de la mise en page originale finie.

Coordonnées du comité d'organisation:

21037, Ukraine, Vinnytsia, st. Zodchih, 18, bureau 81

Plateforme scientifique européenne

Téléphones: +38 098 1948380; +380981956755

E-mail: info@ukrlogos.in.ua

URL: www.ukrlogos.in.ua 